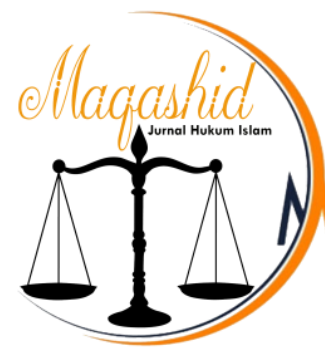

Al-Ahwal Al-Syakhsiyah, IAI Al-Qolam

Maqashid (2020) Vol.3. No.l: 1-16

http://ejournal.alqolam.ac.id/index.php/maqashid

p-ISSN: 2613-9758

e-ISSN : 2685-4619

(c) Maqashid 2020

\title{
Perlindungan Nasab dalam Teori Maqashid Syariah
}

\section{Achmad Beadie Busyroel Basyar}

Warek III Institut Agama Islam Al-Qolam

Email: bedi@alqolam.ac.id

\begin{tabular}{|c|c|}
\hline ARTICLE INFO & ABSTRACT \\
\hline $\begin{array}{l}\text { Article History } \\
\text { Recieved Maret } 2020 \\
\text { Accepted April } 2020 \\
\text { Available Mei } 2020\end{array}$ & $\begin{array}{l}\text { Kemaslahatan sebagai inti dari maqâshid al-syarî‘ah, } \\
\text { memiliki peranan penting dalam pengembangan hukum } \\
\text { Islam. Sebab hukum Islam diturunkan dengan tujuan untuk } \\
\text { menghadirkan kemaslahatan manusia baik di dunia maupun } \\
\text { di akhirat. Salah satu kemaslahatan yang diayomi adalah } \\
\text { perlindungan nasab. Nasab adalah fitrah manusia, karena } \\
\text { manusia memiliki naluri beregenerasi. Di sisi lain, manusia } \\
\text { memiliki fitrah kepatuhan kepada Tuhan. Sehingga dua fitrah } \\
\text { tersebut terakumulasi pada perlindungan nasab. Perlindungan } \\
\text { nasab berkenaan dengan kuantitas di satu sisi, dan kualitas di } \\
\text { sisi lain. Proporsional titik yang tepat dari keduanya dilihat } \\
\text { dari lingkup realitas yang terikat. Perlindungan nasab tidak } \\
\text { hanya pada regenerasi saja, tapi juga mencakup pada segala } \\
\text { perantara (wasilah) yang menunjangnya, baik pada kuantitas } \\
\text { maupun kualitas. Pun demikian, perlindungan nasab } \\
\text { mengakomodir sisi potensi ke depan (janib al-wujud) untuk } \\
\text { dioptimalkan, dan sisi riil terkini untuk dipertahankan (janib } \\
\text { al-'adam). }\end{array}$ \\
\hline
\end{tabular}




\section{Pendahuluan}

Syariat adalah hukum Allah swt yang mencakup segala hal. Dengan kata kunci bahwa syariat hadir untuk kemaslahatan manusia, baik di dunia maupun akhirat. ${ }^{1}$ Persoalan realitas kehidupan terus berkembang, maka upaya kemaslahatan tersebut juga turut berkembang. Hingga saat ini, persinggungan antara syariat dengan maslahat realitas tersebut banyak dibicarakan oleh pakar, khususnya kajian keislaman maqashid syariah. Persinggungan syariat dan realitas merupakan suatu yang pasti. Karena syariat seharusnya lahir dari proses integrasi dialektik antara nas, akal dan realitas. ${ }^{2}$ Hukumhukum pada syariat itu tidaklah dibuat untuk hukum itu sendiri, melainkan dibuat untuk tujuan lain yakni kemaslahatan. ${ }^{3}$

Semua perintah dan larangan Allah yang terdapat dalam Al-Qur'an, begitu pula perintah dan larangan Nabi Muhammad SAW yang ada dalam Hadits, yang diasumsikan ada keterkaitan dengan hukum memberikan kesimpulan bahwa semuanya mempunyai tujuan tertentu dan tidak ada yang sia-sia. Semuanya mempunyai hikmah yang mendalam, yaitu sebagai rahmat bagi umat manusia. ${ }^{4}$

Kajian maqashid syariah ini memberikan peluang untuk menemukan ruh makna dari hukum syariat. Di mana pada nantinya kerangka besar dari syariat dapat terlihat, dan menjadi acuan dalam pengembangan hukum syariat itu sendiri. Hingga dapat terlihat cakupan luas syariat pada segala aspek kehidupan manusia. Hal itu karena syariat adalah petunjuk, obat, dan rahmat bagi manusia. ${ }^{5}$ Sebagai petunjuk, syariat akan senantiasa terjadi dialek dengan realitas kehidupan manusia, termasuk persoalan anak dan generasi. Dialektika tersebut baik tentang realitas saat ini, maupun di masa mendatang, baik pengupayaan meningkatkan positif maupun menekan yang negatif.

Penelitian ini bertujuan untuk memahami salah satu hikmah syariat berupa: perlindungan nasab, serta pengembangannya pada beberapa tema realitas kehidupan. Kerangka perlindungan nasab yang dimaksud tentunya tidak hanya pada persoalan pernikahan dan zina. Di mana dua tema tersebut adalah tema manshush. Tetapi juga meliputi segala lini kehidupan manusia yang berkenaan dengan keturunan.

\footnotetext{
${ }^{1}$ Abu Ishaq As-Syatibi, al-Muwafaqat fi Ushul as-Syariah (Beirut: Dar Kotob Ilmiyah, 2004 ), hal. 7.

${ }^{2}$ Wahbah az-Zuhaily, Taghayyur Al-Ijtihad (Damaskus: Darl al-Maktabi, 2000), hlm. 8 - 9

${ }^{3}$ Fathi Daryni, al-Manâhij al-Ushûliyyah fì Ijtihâd bi al-Ra'yi fì al-Tasyrî' (Damaskus: Dâr al-Kitâb alHadîts, 1975), hlm. 28

${ }^{4}$ Lihat: Ghafar Shidiq, “Teori Maqâshid Al-Syarî'ah Dalam Hukum Islam”, Jurnal Sultan Agung, Vol XLIV No. 118 Juni-Agustus 2009, hlm. 120.

${ }^{5}$ Muhammad Abu Zahrah, Ushûl Al-Fiqh,Saefullah Ma'shum (pent.), (Jakarta: Pustaka Firdaus, 2000) hlm. 552 .
} 


\section{Pengertian Maqashid Syariah}

Secara bahasa syariah bermakna jalan yang terang. Di dalam al-Quran disebutkan:

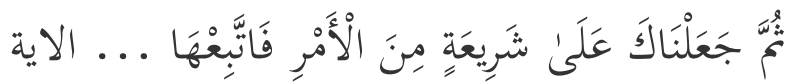

Kemudian Kami menjadikanmu (wahai Rasul) di atas jalan yang terang dalam perkara (agama), maka ikutilah itu ... ${ }^{6}$

Pada ayat tersebut, Al-Farra' menafsiri kata jalan yang lurus di atas dengan "tradisi, agama, dan cara hidup",

Dalam istilah yang dikehendaki, syariah adalah hukum yang ditetapkan Allah swt melalui Rasul-Nya, tentang segala perilaku manusia, baik berkenaan dengan hubungannya dengan Allah swt, maupun dengan sesama makhluknya. ${ }^{8}$ Sehingga cakupan syariah adalah perbuatan, keyakinan, dan etika. Sedangkan fikih adalah hukum Allah swt yang hanya berkenaan dengan perbuatan manusia. ${ }^{9}$ Dari hal tersebut, dapat dipahami bahwa syariat yang berkenaan dengan perilaku manusia disebut dengan fikih.

Pada perkembangannya, ketika dilakukan upaya pengerucutan, ditemukan bahwa segala hukum dalam fikih menuju pada titik-titik tertentu, yakni poin kemaslahatan. Poin-poin kemaslahatan tersebut yang kemudian dikenal dengan maqashid syariah.

Maqashid syariah dalam pengertian bahasa berarti tujuan-tujuan dari suatu jalan atau tradisi, apapun tradisinya. Suatu tempat yang didatangi karena alasan-alasan tertentu adalah syariat, dan maqashid syariah berarti maksud dan tujuan untuk mendatangi tempat tersebut. Az-Zuhaili memberikan pengertian yang mirip dengan apa yang disampaikan al-Fasi, menurut Zuhaili maqashid Syariah adalah makna dan hikmah yang dipertimbangkan oleh syariat dalam hukum, baik semua hukum atau sebagian besar dari hukum yang ada, atau maqashid Syariah adalah hikmah yang terkandung pada tiap-tiap hukum yang ditentukan syariat."10

Tujuan dari maqashid syariah adalah memberikan kemaslahatan bagi manusia, dan menghindarkannya dari segala keburukan. Al-Ghazali menyebutkan maqashid syariah adalah ungkapan yang berisikan pengayoman pada keberadaan diri (dengan menolak kerusakan) dan upaya mewujudkan sarana kemaslahatan. ${ }^{11}$

Adapun ahli ushûl al-fiqh yang membahas konsep Maqâshid al-Syarî‘ah secara khusus, sistematis dan jelas adalah Abu Ishaq al-Syathibi. Melalui karyanya yang berjudul al-Muwâfaqât beliau menyatakan secara tegas bahwa tujuan Allah swt

\footnotetext{
${ }^{6}$ QS. Al-Jatsiyah (45): 18.

${ }^{7}$ Abu Zakariya al-Farra', Ma'ani al-Qur'an (Beirut: Alamul Kotob, 1403 H), juz. 3, hal. 46.

${ }^{8}$ Lihat: Ibn Taimiyah, Majmu al-Fatawa (Makkah: Maktabah Nahdah Hadisiyah, tt), juz 19, hal. 306.

${ }^{9}$ Zakariya al-Anshari, Ghayah al-Wushul fi Syarh Lubb al-Ushul (Mesir: Dar Kotob Arabiyah Kubra, tt), juz 1, hal. 6.

${ }^{10}$ Wahbah az-Zuhaili, Ushul al-Fiqh al-Islami (Sirya: Darul Fikr, 1406 H), juz 2, hal. 1017.

11 Abu Hamid al-Ghazali, Syifa' al-Ghalil fi Bayan asy-Syabh wa al-Mukhil wa Masalik at-Tahlil (Baghdad: Penerbit al-Irsyad, 1390 H), hal.
} 
mensyariatkan hukum-Nya adalah untuk kemaslahatan manusia, baik di dunia maupun di akhirat. $^{12}$

Poin-poin kemaslahatan tersebut dirangkum dalam hirarki maqashid syariah. Pertama, dharuriyat, yakni kemaslahatan yang harus ada untuk menghasilkan maslahat agama maupun dunia, yang andaikan tak terpenuhi, maka berdampak hidup menjadi kacau, rusak, dan bahkan kemusnahan, juga berdampak pada hilangnya keselamatan dan kenikmatan di akhirat, serta menuju pada kerugian yang jelas. ${ }^{13}$ Kedua, hajiyat, yakni kemaslahatan yang jika tidak ada berdampak pada suatu kerusakan, tetapi tidak sampai pada tingkat kerusakan yang pada dharuriyat. As-Syatibi mengartikan hajiyat adalah segala hal yang dibutuhkan sebagai penunjang, terhindar dari kerumitan dan kesulitan. Jika hal-hal hajiyat ini tidak terlindungi, maka berdampak pada kerusakan atau keburukan, hanya tidak seburuk kerusakan yang timbul dari maslahat umum (dharuriyat). ${ }^{14}$ Ketiga, takmiliyah atau tahsiniyah, yakni kemaslahatan yang memberikan nilai lebih, memaksimalkan kebaikan, dan ketika tidak terpenuhi tidak berdampak pada keburukan.

Ada lima poin besar dari hirarki dharuriyat, yaitu: agama, jiwa, nasab (keturunan), akal, harta. Al-Ghazali menyebutkan: ${ }^{15}$

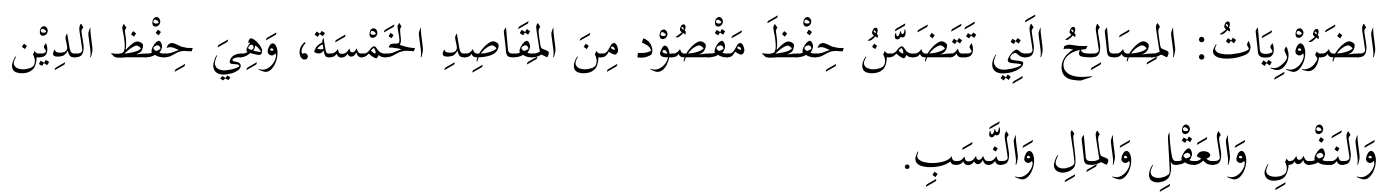

Dharuriyat adalah maslahat yang tertuang pada saat menjaga satu dari lima tujuan, yakni agama, jiwa, akal, harta, dan nasab.

Lima poin ini dikenal dengan beberapa istilah: dharuriyat khams, ushul khams, dan kulliyat khams. Yang menjadi poin pembahasan dari lima poin tersebut dalam penelitian ini adalah perlindungan nasab.

\footnotetext{
12 Ali Mutakin, "Teori Maqashid Syariah dan Hubungannya dengan Metode Istinbath Hukum", Kanun Jurnal Hukum Islam, vol. 19 (Agustus, 2017), hal. 553.

${ }^{13}$ Abu Ishaq As-Syatibi, al-Muwafaqat fi Ushul as-Syariah (Beirut: Dar Kotob Ilmiyah, 2004 ), hal. 221.

${ }^{14}$ Abu Ishaq As-Syatibi, al-Muwafaqat ..., juz. 2, hal. 11.

${ }^{15}$ Al-Ghazali, al-Mustashfa min Ilm al-Ushul (Beirut: Darul Fikr, tt), juz. 2, hal. 251.
} 


\section{Perlindungan Nasab}

Perlindungan nasab atau juga diistilahkan hifz an-nasl, pada berbagai literatur ada perbedaan penyebutan istilah mengenai perlindungan nasab ini. Ada yang menyebut kata nasl, ada kata nasab, ada pula yang menyebut kata budh'. ${ }^{16}$ Perbedaan dari tiga istilah tersebut adalah: a) nasl berarti garis keturunan ke atas, misalnya ayah, ayahnya ayah, ayahnya ibu, dan seterusnya, b) nasab adalah garis keturunan ke bawah, anak, cucu, dan seterusnya, c) budh' berarti kelamin perempuan.

Dilihat dari makna masing-masing istilah yang digunakan, istilah yang paling tepat adalah istilah pertama (nasl). Karena muatan yang dilindungi pada dasarnya terletak pada garis keturunan. Kemaslahatan utama yang dilindungi syariat melalui poin ini adalah keberlangsungan suatu generasi manusia, untuk mencegahnya dari kepunahan, dengan upaya-upaya yang mengacu pada kebaikan di dunia dan akhirat. Dan maslahat tersebut tertuang lebih jelas pada istilah nasl, yang berarti keturunan. Sedangkan pada istilah nasab, gambaran yang dilihat adalah garis keturunan seseorang dari atas. Hampir tidak ada kaitannya dengan maslahat yang dimaksud. Begitu pula dengan istilah budh' (alat kelamin), hampir tidak ada kaitan langsung dengan maslahat yang dimaksud, karena alat kelamin hanyalah sebagai sarana bagi keberlangsungan manusia. Karena itulah ArRaisuni menjelaskan penggunaan kata nasl itu lebih baik dari kata nasab, karena nasl adalah tujuannya dan nasl pula yang mencapai level prioritas (dharuriyat) untuk dijaga, sedangkan nasab hanyalah bagian dari perantara untuk mencapai keterjagaan nasl. ${ }^{17}$

Hukum-hukum yang muncul dari perlindungan nasab ini banyak sekali. Secara garis besar ada dua peninjauan, yaitu:

1. Menjaga eksistensi nasl agar tetap berlangsung, dengan cara mengupayakan hal-hal yang memaksimalkan hadirnya keturunan yang baik dan ideal. Dari peninjauan pertama ini muncullah hukum-hukum syariat seperti berikut:

a. Dianjurkannya menikah, memilih pasangan yang baik, menikahi perempuan yang berpotensi banyak melahirkan anak, diperbolehkannya poligami, dan lainnya.

b. Diwajibkannya bagi orang tua untuk mendidik anaknya, khususnya tentang prinsip-prinsip utama dalam Islam.

c. Dianjurkannya menjaga kesehatan alat reproduksi.

\footnotetext{
${ }^{16}$ Saad al-Yubi melakukan penelusuran terhadap penggunaan tiga istilah tersebut: a) nasab digunakan oleh ar-Razi, Ibnu Qudamah, al-Baidhawi, al-Qarafi, Shadr Syariah al-Mahbubi, at-Tufi, al-Ashfihani, Ibnu Subki, Kamal bin Hammam, al-Mahalli, Ibnu Amir Hajj, Zakariya al-Anshari, Shahib al-Muraqi, Ibnu Budran, dan Isa Mannun, b) nasl digunakan oleh al-Ghazali, al-Amudi, Ibnul Hajib, Aduddin al-Iji, azZarkasyi, as-Syatibi, Muhammad al-Futuhi, dan as-Syaukani, c) sedangkan budh' digunakan oleh Imam Haramain, Ibnu Taimiyah, dan al-Ghazali dalam Syifa al-Ghalil. Lihat: Muhammad Sa'ad al-Yubi, Maqashid as-Syariah al-Islamiyah wa Alaqatuha bi al-Adillah as-Syar'iyah (Riyad: Dar al-Hijrah, 1998), hal. 245-247.

${ }^{17}$ Ahmad Ar-Raisuni, Nadzariyat al-Maqashid Inda as-Syatibi (Riyad: an-Najah, 1411 H), hal. 42.
} 
2. Menjaga nasl dari kerusakan yang menghampiri, dengan cara menghindarkan hal-hal yang membuat keturunan menjadi rusak, habis, dan tidak baik. Dari penijauan kedua ini dapat tergambar dengan melihat hukum-hukum seperti berikut:

a. Tidak dianjurkannya hidup menjomblo seterusnya, baik karena alasan untuk fokus ibadah ${ }^{18}$, maupun alasan yang lain.

b. Diharamkannya penyalahgunaan seksual pada selain yang halal, seperti zina, sodomi, dan lainnya.

c. Dilarangnya merusak alat reproduksi atau mengkonsumsi sesuatu sehingga menyebabkan tidak bisa memiliki anak, baik pada laki-laki maupun perempuan. $^{19}$

d. Dilarang melakukan aborsi janin. ${ }^{20}$

\section{Pengembangan Perlindungan Nasab}

\section{Dua Fitrah dalam Perlindungan Nasab}

Perlindungan nasab - seperti ulasan sebelumnya - adalah untuk melindungi keberlangsungan manusia agar tidak terjadi kepunahan, dengan cara yang merujuk pada kebaikan manusia di dunia dan akhirat. Keberlangusngan tersebut merupakan fitrah dari manusia, bahwa manusia - sebagai makhluk hidup - memiliki fitrah untuk menduplikasi diri, bereproduksi, dan melanjutkan kehidupan pada generasi berikutnya. Fitrah-fitrah semacam ini lalu diakomodir oleh syariat, karena syariat memiliki tujuan untuk menghadirkan kemaslahatan bagi manusia. Di mana salah satu kemaslahatan itu adalah

\footnotetext{
${ }^{18}$ Banyak hadis Nabi menjelaskan tentang ini, salah satunya hadis tentang tiga orang yang merasa jauh derajat Nabi, lantas akan fokus shalat, puasa, dan satu lagi tidak akan menikah. Nabi saw pun menjawab, "Demi Allah, aku adalah orang yang paling takut dan takwa kepada Allah daripada kalian, tetapi aku berpuasa dan tidak, aku juga shalat dan tidur, aku juga menikahi beberapa perempuan. Menikah adalah sunahku, siapa yang enggan dengan sunahku, maka bukan bagianku." (HR. Bukhari Muslim)

${ }^{19}$ Lihat fatwa Izzuddin bin Abdissalam tentang diharamkannya perempuan yang mengkonsumsi apapun untuk mencegah agar tidak hamil lagi. Izzuddin bin Abdissalam, Kitab al-Fatawa (Beirut: Darul Makrifat, 1986), hal. 152. Akan tetapi jika konsumsi obat tersebut hanya untuk mengatur, tanpa menghilangkan potensi memiliki anak, maka itu tidak diharamkan. Lihat: as-Syarqawi, Hasyiyah ala Tuhfah at-Tullab (Beirut: Darul Fikr, tt), juz. 2, hal. 332, al-Jamal, Hasyiyah ala al-Manhaj (Beirut: Darul Fikr, tt), juz. 4, hal. 447.

${ }^{20}$ Dalam fikih menggugurkan kandungan, baik dengan obat atau operasi disebut dengan Ijhadh atau isqath haml. Jika kandungan telah berumur 120 hari atau lebih (telah ditiupkan ruh), maka tidak diperbolehkan menggugurkan kandungan, kecuali jika secara medis kandungan membahayakan bagi ibunya, maka termasuk mudarat yang memperbolehkan demi kehidupan ibunya. Jika kandungan belum 120 hari, terdapat perbedaan pendapat di kalangan ulama, mayoritas tetap mengharamkannya, akan tetapi andai ada keterangan medis bahwa kandungan akan terlahir buruk yang sulit diobati, maka diperbolehkan untuk digugurkan. Tanpa ada alasan-alasan tersebut, menggugurkan kandungan tidak diperbolehkan. Lihat hasil keputusan ulama Mekkah pada Sabtu, 10 Februari 1990 - Sabtu, 17 Februari 1990, yang dikutip pada: Abdullah al-Bassam, Taudih al-Ahkam min Bulugh al-Maram (Mekkah, Penerbit al-Asadi, 2003), juz. 6, hal. 102, lihat juga: Ibnu Hajar al-Asqalani, Fath al-Bari bi Syarh al-Bukhari (Riyad, Penerbit Malik Fahd, 2001), juz.9, hal. 220.
} 
melindungi fitrah manusia itu sendiri, dalam hal ini fitrah beregenerasi. Fitrah tersebut disebut dengan sibghah fitriyah (karakter asli) dari manusia.

Sibghah al-fithriyah tidak berbeda kedudukannya dengan kaidah perilaku yang harus sejalan dengan tuntutan fitrah manusia. Fitrah adalah kondisi naluri yang berhubungan dengan moral dan spiritual yang menggerakkan jiwa manusia dan mengantarnya untuk mengetahui dan menyadari kehambaan dirinya kepada Tuhan. ${ }^{21}$ Fitrah manusia tersebut salah satunya adalah karakter manusia untuk beregenerasi, dan melanjutkan kehidupan pada generasi berikutnya.

Sifat-sifat moral pada al-qushud al-syar'iyah (tujuan syariat) ada dua, yaitu: assibgah al-iradiyah (karakter kehendak) dan as-sibgah at-tajarrudiah (karakter ketaatan dan keikhlasan). ${ }^{22}$ Di satu sisi manusia memiliki kehendak, sedangkan di sisi lain, manusia (dituntut) untuk sesuai dengan ketulusan dan kepatuhan kepada Tuhan. Dua sisi moral ini berjalan seimbang dan saling terikat. Artinya manusia dalam melakukan kehendak dibatasi pada kepatuhan, sehingga tidak menodai moral ketulusannya. Ketika manusia itu melakukan ketaatan, manusia diberi ruang untuk berkehendak, sehingga diberi pilihan-pilihan dalam melakukannya, selagi tidak bertentangan dengan niat ketulusan tersebut.

Dalam kaitannya dengan kuantitas populasi, manusia memiliki fitrah untuk beregenerasi, untuk mencegah dari kepunahan. Di sisi lain, fitrah manusia adalah kepatuhan kepada Tuhannya, dengan tetap menjaga kebaikan di akhiratnya. Sehingga upaya untuk mempertahankan populasi ditentukan dalam koridor kepatuhan pada Tuhannya. Dari situlah dapat dipahami dalam syariat upaya memiliki anak (generasi) hanya bisa dilakukan dengan cara yang benar dan baik, yaitu anjuran menikah dan membangun keluarga dengan baik.

Meningkatkan populasi dengan cara yang tidak baik, seperti seks bebas, pornografi, dan lainnya, hanya mengindahkan satu fitrah saja: fitrah beregenerasi, tetapi tidak mengindahkan fitrah yang lain: fitrah kepatuhan. Sehingga upaya peningkatan dengan cara-cara tersebut tidak dibenarkan. Fitrah kepatuhan ini didasari atas poin perlindungan terhadap agama, bahwa manusia secara fitrahnya merupakan makhluk yang patuh kepada Tuhannya dan melaksanakan keberagamaan yang baik.

\section{Perlindungan Nasab dalam Keluarga Berencana}

Perlindungan nasab dalam kaitannya untuk melindungi keberlangsungan manusia agar tidak terjadi kepunahan, terdapat dua hal peninjauan: kuantitas dan kualitas. Jumlah kuantitas manusia yang tinggi adalah satu poin yang dituju. Sedangkan di sisi lain, kualitas populasi adalah poin lain dari perlindungan nasab. Hal itu dikarenakan kuantitas yang tidak dijaga kualitasnya, justru berdampak pada potensi mafsadah pada beberapa

\footnotetext{
${ }^{21}$ Mth, Asmuni. "Studi Pemikiran Al-maqashid (Upaya Menemukan Fondasi Ijtihad Akademik yang Dinamis)." Al-Mawarid Journal of Islamic Law, vol. 14, 2005. hal. 170.

${ }^{22}$ Mth, Asmuni. "Studi Pemikiran Al-maqashid (Upaya Menemukan Fondasi Ijtihad Akademik yang Dinamis)." Al-Mawarid Journal of Islamic Law, vol. 14, 2005. hal. 170.
} 
lini lain dari manusia, seperti kesehatan, akses pendidikan, kecukupan pangan, dan lainnya. Maka kemudian muncul istilah keluarga berencana (KB).

Menurut Masri Singarimbun, Keluarga berencana di Indonesia yang secara resmi diintegrasikan dalam program pembangunan sejak Pelita I (1969/1970) secara umum diupayakan untuk pembangunan kependudukan dan upaya mengatasi besarnya jumlah penduduk, tingkat pertumbuhan penduduk yang tinggi disebabkan tingkat kelahiran yang tinggi pula dan penyebaran penduduk yang kurang merata antara Pulau Jawa, Madura, Bali dan Lombok Dengan pulau lain. Di samping itu juga diarahkan untuk mengatasi terlalu besarnya jumlah penduduk yang mata pencahariannya dalam bidang pertanian dan kondisi sosial-ekonomi penduduk yang rendah, itu antara lain ditunjukkan oleh tingkat pendidikan dan kesehatan penduduk yang belum memadai. ${ }^{23}$

Pada keluarga berencana, pasangan suami-istri mengatur dan membatasi jumlah keturunannya. Motivasi itu didorong oleh beberapa faktor, seperti kesehatan, gizi, kekhawatiran rizki, dan lain sebagainya.

Syariat menganjurkan untuk memperbanyak keturunan dan mensyukuri setiap anak yang lahir, laki-laki maupun perempuan. Namun di balik itu, Syariat juga menyerukan kepada setiap muslim untuk mengatur keturunannya demi kualitas generasi berikutnya. Dalam al-Quran Allah swt berfirman:

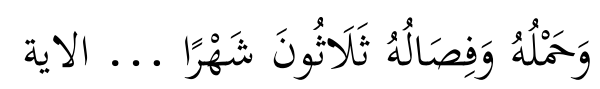

Mengandungnya sampai menyapihnya adalah tiga puluh bulan ... ${ }^{24}$

Al-Qurtubi menjelaskan tiga puluh bulan tersebut adalah jumlah total dari masa kehamilan dan menyusui. Sehingga jika hamilnya 6 bulan, maka menyusuinya 24 bulan. Jika hamilnya 7 bulan, menyusuinya 23 bulan. Dan begitu seterusnya. ${ }^{25}$ Gizi terbaik bagi anak adalah air susu ibu, jika anak kekurangan air susu ibu, karena lebih cepat disapih, maka hal itu mengurangi potensi kesehatan anak tersebut. Selain itu, jika jarak kehamilan kurang dari tiga puluh bulan ada kemungkinan terkena resiko buruk, seperti kesehatan ibu atau calon anak akan terganggu, dan menjadi lemah.

Dalam istilah Arab dikenal ghilah atau ghailah, yakni kondisi seorang ibu menyusui sekaligus hamil. Rasulullah saw memperingatkan supaya tidak hamil bila dalam keadaan menyusui karena berdampak buruk bagi anak maupun si ibu. Rasulullah saw bersabda:

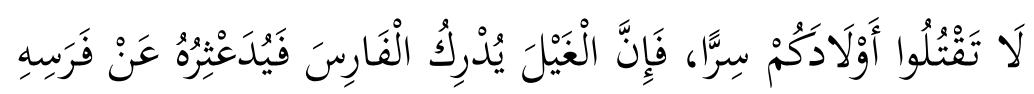

Janganlah kamu membunuh anak-anakmu secara diam-diam, karena ghail (perempuan hamil yang menyusui anaknya) itu mengejar penunggang kuda (pendekar) lalu dijungkalkan dari kudanya. ${ }^{26}$

\footnotetext{
${ }^{23}$ Masri Simarimbun dalam Cholil Nafis, Fikih Keluarga; Menuju Keluarga Sakinah Mawaddah wa Rahmah; Keluarga Sehat Sejahtera dan Berkualitas (Jakarta Selatan: Mitra Abadi Press, 2014), hal.72.

${ }^{24}$ QS. Al-Ahqâf (35): 15.

${ }_{25}$ Al-Qurtubi, Al-Jami' li Ahkam Al-Qur'an (Mesir, Dar Asy-Sya'bi, 1372 H), juz. 14, hal. 180-181.

${ }^{26}$ Abu Daud as-Sijistani, Sunan Abi Daud, juz 6, (Beirut: Risalah Alamiyah, 2009), nomor hadis 3881, hal. 12.
} 
Ketika seorang ibu hamil sekaligus menyusui, potensi buruk terjadi pada ketigatiganya: anak yang disusui, si ibu, dan anak yang berada dalam kandungan. Ghilah ini adalah suatu bentuk kriminalitas yang sangat rahasia (tidak secara langsung) terhadap anak yang sedang disusui. Oleh karena itulah Rasulullah saw kemudian melarangnya.

Keluarga berencana merupakan suatu upaya untuk menjamin kualitas anak, khususnya dari sisi kesehatan, baik ketika masih di dalam kandungan maupun pasca dilahirkan. Karena hal itu, syariat mendorong keluarga berencana ini. ${ }^{27}$ Dari program keluarga berencana, peningkatan populasi manusia dan kualitas manusia dapat diupayakan secara bersama.

\section{Perlindungan Nasab dan Kependudukan}

Jumlah populasi manusia dari sisi kuantitas adalah mata pisau berbilah dua. Di satu sisi, populasi tersebut merupakan sebuah potensi besar, karena kian besar jumlahnya, kian besar pula potensi kekuatan yang dapat dimaksimalkan. Namun di sisi lain, kuantitas besar membutuhkan sumber daya manusia yang memadai. Tanpa hal tersebut, kuantitas populasi yang besar justru berpotensi menimbulkan kekacauan dan keburukan, seperti ketidakmerataan akses, tidak cukupnya pasokan dan kebutuhan, termasuk kesehatan.

Berdasarkan survei penduduk antar sensus (Supas) 2015 jumlah penduduk Indonesia pada 2019 diproyeksikan mencapai 266,91 juta jiwa. Menurut jenis kelamin, jumlah tersebut terdiri atas 134 juta jiwa laki-laki dan 132,89 juta jiwa perempuan. ${ }^{28}$ Tingkat fertilitas (jumlah kelahiran) 4,4 juta jiwa per tahun, dan mortalitas (jumlah kematian) 1,6 juta jiwa per tahun. ${ }^{29}$ Dari data tersebut, saat ini, ada 12.000 kelahiran dan 4.300 kematian tiap hari di Indonesia.

Jika dikaitkan dengan perlindungan nasab dalam syariat, terdapat dua peninjauan mengenai fertilitas. Pertama, anjuran meningkatkan fertilitas. Dalam Hadis disebutkan:

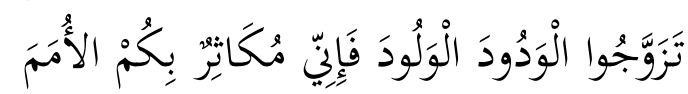

Nikahilah perempuan yang memiliki kasih sayang dan banyak anak, karena sesungguhnya aku akan memperlihatkan kamu di depan umat-umat. ${ }^{30}$

Kedua, perintah memperhatikan generasi agar menjadi generasi yang berkualitas. Dalam al-Quran disebutkan:

\footnotetext{
${ }^{27}$ Cholil Nafis, Fikih Keluarga; Menuju Keluarga Sakinah Mawaddah wa Rahmah; Keluarga Sehat Sejahtera dan Berkualitas (Jakarta Selatan: Mitra Abadi Press, 2014), hal.77.

28 Redaksi, "Jumlah Penduduk Indonesia 2019 Mencapai 267 Juta Jiwa”, Databoks, https://databoks.katadata.co.id/datapublish/2019/01/04/jumlah-penduduk-indonesia-2019-mencapai-267juta-jiwa, (10 Maret 2020)

${ }^{29}$ Redaksi, "2015-2045: Angka Kematian Terus Naik, Angka Kelahiran Relatif Stabil”, Databoks, https://databoks.katadata.co.id/datapublish/2019/07/18/2015-2045-angka-kematian-terus-naik-angkakelahiran-relatif-stabil, (10 Maret 2020)

30 Abu Daud as-Sijistani, Sunan Abi Daud, juz 3, (Beirut: Risalah Alamiyah, 2009), nomor hadis 2050, hal. 151 .
} 

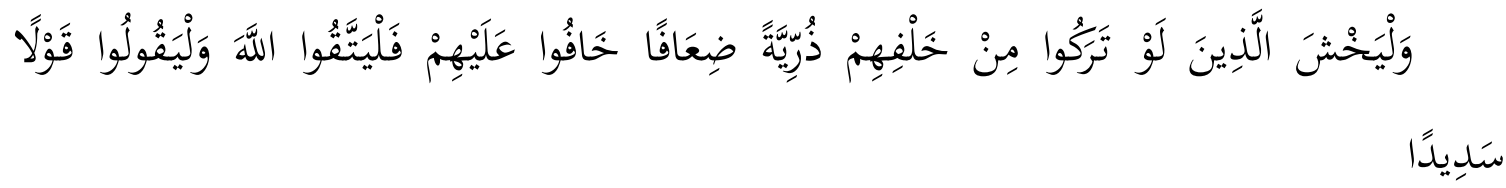

Dan hendaklah takut kepada Allah orang-orang yang seandainya meninggalkan di belakang mereka anak-anak yang lemah, yang mereka khawatir terhadap (kesejahteraan) mereka. Oleh sebab itu hendaklah mereka bertakwa kepada Allah dan hendaklah mereka mengucapkan perkataan yang benar. ${ }^{31}$

Pada ayat tersebut jelas Allah swt mengingatkan kaum muslimin untuk tidak meninggalkan generasi yang lemah. Karena generasi yang lemah menyebabkan umat lemah dan kalah bersaing dengan umat-umat lainnya.

Syariat melalui dua peninjauan tersebut memberikan gambaran keseimbangan ideal antara kuantitas dan kualitas. Islam memandang bahwa esensinya bukan pada peningkatan atau penurunan pertumbuhan penduduk, melainkan pada kesejahteraan dan kualitas masyarakatnya. ${ }^{32}$ Belum tentu pertumbuhan penduduk yang tinggi dianggap keadaan yang jelek atau membahayakan, demikian juga sebaliknya. Karena pada suatu keadaan tertentu fertilitas yang tinggi diperlukan, dan pada suatu keadaan tidak diperlukan. Islam lebih mengedepankan esensi kemaslahatan kehidupan. Untuk itu, perlindungan nasab dipahami juga sebagai dorongan untuk meningkatkan kualitas generasi penerus.

\section{Perlindungan Kesehatan Organ Reproduksi}

Pada maqashid syariah, suatu poin tujuan (maqshad) memiliki penunjang dan perantara (wasilah). ${ }^{33}$ Ibnu Asyur menjelaskan bahwa suatu maslahat dan keburukan terbagi menjadi dua: a) maqashid, yaitu hal-hal yang memiliki maslahat atau keburukan secara mandiri dan sebagai tujuan, b) wasail, yakni hal-hal yang tidak memiliki maslahat atau keburukan secara mandiri, hanya sebagai pengantar bagi suatu tujuan. ${ }^{34}$ Penunjang memiliki gradasi dalam kekuatannya mewujudkan tujuan. Dan bahkan suatu wasilah memiliki penunjang lagi untuk mewujudkannya. ${ }^{35}$ Kriteria penunjang ini haruslah tidak justru menafikan maqashid. ${ }^{36}$

Untuk melindungi nasab (kuantitas dan kualitas generasi), salah satu upaya yang dilakukan adalah menjaga kesehatan alat reproduksi. Sistem reproduksi wanita terdiri dari beberapa organ yang dirancang untuk menjalankan beberapa fungsi. Sistem reproduksi wanita tidak hanya berfungsi sebagai tempat pembuahan, namun juga

\footnotetext{
${ }^{31}$ QS. An-Nisa (3): 9.

32 Cholil Nafis, Fikih Keluarga; Menuju Keluarga Sakinah Mawaddah wa Rahmah; Keluarga Sehat Sejahtera dan Berkualitas, hal.144.

${ }^{33}$ Dalam istilah maqashid syariah, penunjang maslahat disebut dengan wasilah, sedangkan penunjang mafsadat (keburukan) dikenal dengan dzari'ah. Secara bahasa keduanya memiliki makna yang sama.

${ }^{34}$ Ibnu Asyur, Maqashid as-Syariah al-Islamiyah (Tunisia: as-Syirkah, 1978), hal. 252.

${ }^{35}$ Lihat: Izzuddin bin Abd Salam, Qawaid al-Ahkam fi Masalih al-Anam (Beirut: Darul Makrifat, 1996), juz 1, hal. 105.

${ }^{36}$ Abu Ishaq As-Syatibi, al-Muwafaqat fi Ushul as-Syariah (Beirut: Dar Kotob Ilmiyah, 2004), hal. 228.
} 
menghasilkan hormon pada wanita untuk menjaga siklus reproduksi. Organ-organ ini ini berperan penting dalam hubungan seksual, produksi dan perkembangan sel telur, menstruasi, kehamilan, hingga proses persalinan. ${ }^{37}$

Organ reproduksi ini dijaga kesehatannya tidak hanya ketika hamil atau akan melahirkan. Tetapi juga kesehatan ibu yang disebut juga sebagai kesehatan maternal, merupakan bagian dari kesehatan reproduksi perempuan yang mencakup kesehatan reproduksi sejak remaja, saat sebelum hamil, hamil, persalinan, dan sesudah melahirkan.

Upaya yang dapat dilakukan untuk menjaga organ reproduksi ini misalnya: a) menjaga kebersihan organ, b) mengelola stres, c) mengkonsumsi makanan sehat, d) menjaga IMT (indeks massa tubuh) ideal ${ }^{38}$, e) pola hidup sehat. Semua langkah-langkah tersebut dapat meningkatkan kesehatan organ reproduksi, yang pada nantinya meningkatkan potensi memiliki anak yang sehat.

Di sisi lain, angka kematian ibu (AKI) saat melahirkan adalah berkisar 305 per 100.000 menurut Survei Angka Sensus (Supas) tahun 2015. ${ }^{39}$ Faktor kematian tersebut bisa berupa: a) faktor medis, seperti pendarahan, keracunan kehamilan (eklamsia), keguguran, infeksi, persalinan macet, dan lainnya, b) faktor non medis, seperti nutrisi rendah, anemia, terlambat dalam menangani proses kehamilan. Beberapa faktor tersebut berkenaan dengan kesehatan, baik kesehatan organ reproduksi, maupun kesehatan gizi si ibu. Salah satu upaya yang dapat dilakukan untuk mencegah tingginya AKI tersebut adalah meningkatkan kesadaran dan kepahaman terkait dengan proses melahirkan.

Jika dilihat dari maqashid syariah, maka kesehatan organ reproduksi merupakan wasilah dari memiliki anak yang sehat. Dan anak yang sehat adalah bagian dari tujuan yang dikehendaki dari perlindungan nasab. Upaya-upaya untuk memiliki organ reproduksi yang sehat, berarti merupakan penunjang dari penunjang (wasail al-wasilah). Kriteria dari upaya-upaya tersebut adalah tidak dilarang dalam syariat dan tidak berdampak pada rusaknya tujuan.

Mengenai tingginya AKI, kesadaran dan kepahaman tentang proses melahirkan, merupakan wasilah dari meningkatnya potensi hidup. Potensi hidup tertuang dalam perlindungan nyawa (hifz nafs) pada maqashid syariah. Dari hal itu, upaya untuk meningkatkan kesadaran proses melahirkan adalah wasilah dari salah satu tujuan yang dikehendaki dalam syariat.

\footnotetext{
37 Kevin Adrian, "Cara Menjaga Kesehatan Reproduksi Wanita”, Alodokter, https://www.alodokter.com/cara-menjaga-kesehatan-reproduksi-wanita, (11 Maret 2020)

38 IMT dapat ditemukan dengan membagi berat badan $(\mathrm{kg})$ dengan tinggi tubuh kuadrat. IMT ideal berkisar antara 18,5 - 22,9. Lihat: Ajeng Kuamila, "Cara Menghitung Indeks Massa Tubuh (Body Mass Index)", Hellosehat, https://hellosehat.com/hidup-sehat/cara-menghitung-indeks-massa-tubuh-body-massindeks/, (11 Maret 2020)

${ }^{39}$ Kirana, "Di Rakesnas 2019, Dirjen Kesmas Paparkan Strategi Penurunan AKI dan Neonatal”, kesmas, http://www.kesmas.kemkes.go.id/portal/konten/ rilis-berita/021517-di-rakesnas-2019_-dirjen-kesmaspaparkan-strategi-penurunan-aki-dan-neonatal, (11 Maret 2020)
} 


\section{Perlindungan Anak Berkebutuhan Khusus}

Sebagai bagian dari perlindungan nasab, anak dilihat sebagai sebagai anugerah yang patut disyukuri, bagaimanapun kondisinya. Tidak terkecuali jika kondisi anak dalam keadaan cacat atau difabel atau berkebutuhan khusus. Berdasarkan data dari Badan Pusat Statistik (BPS), jumlah anak berkebutuhan khusus (ABK) pada tahun 2017 di Indonesia mencapai angka 1,6 juta anak. ${ }^{40}$ Dari 1,6 juta, hanya $18 \%$ saja mendapatkan layanan pendidikan inklusi.

Seorang anak terlahir sebagai ABK dapat dipengaruhi oleh beberapa faktor yang terjadi dalam beberapa periode, yaitu:

a. Sebelum kelahiran

Penyebab yang terjadi sebelum proses kelahiran, dalam hal ini berarti ketika anak dalam kandungan, terkadang tidak disadari oleh ibu hamil. Faktor-faktor tersebut antara lain, seperti: gangguan genetika, infeksi kehamilan, usia ibu hamil yang tinggi (high risk group), keracunan saat hamil, dan upaya aborsi.

\section{b. Selama proses kelahiran}

Proses kelahiran yang kurang baik dapat pula menyebabkan anak berkebutuhan khusus, seperti: prematur, anoksia ${ }^{41}$, kekurangan oksigen, kehamilan terlalu lama, dan kelahiran menggunakan alat bantu.

\section{c. Setelah kelahiran}

Setelah proses kelahiran pun tidak otomatis bayi aman dari kemungkinan menjadi anak berkebutuhan khusus. Berikut beberapa contoh yang menyebabkan anak menjadi berkebutuhan khusus, seperti: penyakit infeksi bakteri, virus, kekurangan gizi, kecelakaan, dan keracunan. ${ }^{42}$

Persoalan anak berkebutuhan khusus merupakan salah satu persoalan yang kompleks. Karena anak berkebutuhan khusus, sebagai seorang manusia, juga harus diupayakan pemenuhan segala kebutuhannya, baik pasca kelahiran maupun saat anak tersebut tumbuh kian dewasa. Pada saat setelah dilahirkan, ABK membutuhkan penanganan khusus yang tidak sama dengan anak normal. Dan ketika tumbuh berikutnya, ABK membutuhkan perlakuan khusus pula di segala bidang, utamanya pada akses dan penyediaan sumber daya yang dibutuhkan. Terlebih tidak jarang ABK justru malah ditelantarkan oleh orang tua, teman, dan lingkungannya. Sehingga perlu pula diupayakan lembaga-lembaga yang menampung ABK terlantar tersebut.

Dari sudut pandang maqashid syariah, perlindungan nasab - seperti telah disinggung sebelumnya - berarti melindungi generasi penerus, baik kuantitas maupun

\footnotetext{
${ }^{40}$ Hamid Muhammad, "Sekolah Inklusi dan Pembangunan SLB Dukung Pendidikan Inklusi”, Kemdikbud, https://www.kemdikbud.go.id/main/blog/2017/02/sekolah-inklusi-dan-pembangunan-slb-dukungpendidikan-inklusi, (11 Maret 2020)

41 Anoksia adalah kondisi ekstrem yang terjadi ketika tubuh sudah benar-benar kehilangan simpanan oksigen. Anak yang proses kelahirannya terlalu lama bisa mengalami anoksia.

${ }^{42}$ Irwanto, Kasim, \& Rahmi, Analisis Situasi Penyandang Disabilitas di Indonesia (Jakarta: Pusat Kajian Disabilitas Fakultas Ilmu Sosial \& Politik, 2010) hal. 6-11.
} 
kualitas. Makna melindungi ini tidak hanya upaya pada aspek realitas yang belum ada tapi juga realitas yang telah ada. Pada aspek realitas yang belum ada, ruang perlindungan nasab terletak pada peningkatan potensi di masa depan (janib al-wujud). Sedangkan pada aspek realitas yang telah ada, perlindungan nasab mengayomi kondisi terkini semaksimal mungkin agar tetap berjalan baik (janib al-'adam). Saad al-Yubi menjelaskan hifz nasl memiliki dua arah peninjauan: a) menjaga eksistensi nasl agar tetap berlangsung, dengan cara mengupayakan hal-hal yang memaksimalkan hadirnya keturunan yang baik dan ideal, b) menjaga nasl dari kerusakan yang menghampiri, dengan cara menghindarkan hal-hal yang membuat keturunan menjadi rusak, habis, dan tidak baik. ${ }^{43}$

Untuk menghindarkan keturunan dari kerusakan dan keburukan, upaya mengayomi anak harus dilakukan, khususnya ABK, mengingat mereka benar-benar membutuhkan bantuan dari orang lain. Tanpa bantuan dari orang lain, ABK akan sangat sulit untuk bertahan hidup, berkembang, dan hidup secara mandiri.

Di sisi lain, untuk memaksimalkan hadirnya keturunan yang baik, khususnya terhindar dari kelainan, maka perlu ada upaya penyadaran masyarakat tentang faktorfaktor ABK. Sehingga dengan kesadaran itu, jumlah potensi ABK akan dapat dikurangi.

\section{Kesimpulan}

Maqashid Syariah adalah makna dan hikmah yang dipertimbangkan oleh syariat dalam hukum, baik semua hukum atau sebagian besar dari hukum yang ada. Salah satu hikmah (maqashid) tersebut adalah perlindungan nasab, dalam arti melindungi generasi penerus, baik secara kuantitas maupun kualitas.

Perlindungan nasab merupakan salah satu pengayoman syariat atas fitrah manusia (sibghah al-fithriyah). Hanya saja, bentuk aplikatif dari fitrah tersebut harus seimbang antara fitrah berkehendak (as-sibgah al-iradiyah) dan fitrah kepatuhan (as-sibgah attajarrudiah).

Perlindungan nasab ini tidak hanya titik temu dari hukum-hukum fikih yang telah ada, tapi juga berkembang pada tema-tema realitas sosial saat ini. Kepadatan penduduk dan persoalan sumber daya manusia adalah bagian dari tema realitas tersebut. Peningkatan kualitas sumber daya manusia dan program keluarga berencana merupakan upaya perlindungan nasab dari sisi kualitas.

Selain itu, perlindungan nasab dari sisi kualitas juga berkenaan pada perantaranya (wasilah). Organ reproduksi merupakan salah satu wasilah tersebut. Ketika wasilah ini dilindungi, tujuan yang diharapkan juga dapat lebih baik. Perlindungan organ reproduksi tidak hanya ketika hamil atau akan melahirkan. Tetapi juga kesehatan maternal, yakni merupakan bagian dari kesehatan reproduksi perempuan yang mencakup kesehatan reproduksi sejak remaja, saat sebelum hamil, hamil, persalinan, dan sesudah melahirkan.

Nasab yang dilindungi tersebut tidak hanya dilihat pada aspek potensi di masa depan (janib al-wujud), tetapi juga kondisi terkini agar tetap berjalan baik (janib al-

\footnotetext{
${ }^{43}$ Muhammad Sa'ad al-Yubi, Maqashid as-Syariah al-Islamiyah wa Alaqatuha bi al-Adillah as-Syar'iyah (Riyad: Dar al-Hijrah, 1998), hal. 257.
} 
'adam). Termasuk dalam hal tersebut adalah upaya perlindungan anak berkebutuhan khusus (ABK). Terlebih mereka jelas membutuhkan bantuan-bantuan dari pihak lain agar bisa mandiri. 


\section{Daftar Pustaka}

\section{Buku:}

Al-Qur'ân al-Karîm

Al-Bassam, Abdullah (2003). Taudih al-Ahkam min Bulugh al-Maram. Mekkah: Penerbit al-Asadi.

As-Sijistani, Abu Daud (2009). Sunan Abi Daud. Beirut: Risalah Alamiyah.

al-Ghazali, Abu Hamid (1390 H). Syifa' al-Ghalil fi Bayan asy-Syabh wa al-Mukhil wa Masalik at-Tahlil. Baghdad: Penerbit al-Irsyad.

(tt). al-Mustashfa min Ilm al-Ushul. Beirut: Darul Fikr.

As-Syatibi, Abu Ishaq (2004). al-Muwafaqat fi Ushul as-Syariah. Beirut: Dar Kotob Ilmiyah.

Al-Farra', Abu Zakariya (1403 H). Ma'ani al-Qur'an. Beirut: Alamul Kotob.

Ar-Raisuni, Ahmad (1411 H). Nadzariyat al-Maqashid Inda as-Syatibi. Riyad: anNajah.

al-Jamal, Hasyiyah ala al-Manhaj (Beirut: Darul Fikr, tt), juz. 4, hal. 447.

Al-Qurtubi, Al-Jami' li Ahkam Al-Qur'an (Mesir, Dar Asy-Sya'bi, 1372 H), juz. 14, hal. 180-181.

As-Syarqawi (tt). Hasyiyah ala Tuhfah at-Tullab. Beirut: Darul Fikr.

Nafis, Cholil (2014). Fikih Keluarga; Menuju Keluarga Sakinah Mawaddah wa Rahmah; Keluarga Sehat Sejahtera dan Berkualitas. Jakarta Selatan: Mitra Abadi Press.

Daryni, Fathi (1975). al-Manâhij al-Ushûliyyah fì Ijtihâd bi al-Ra'yi fì al-Tasyrî'. Damaskus: Dâr al-Kitâb al-Hadîts.

Ibn Taimiyah (tt). Majmu al-Fatawa. Makkah: Maktabah Nahdah Hadisiyah.

Ibnu Asyur (1978). Maqashid as-Syariah al-Islamiyah. Tunisia: as-Syirkah, 1978.

Al-Asqalani, Ibnu Hajar (2001). Fath al-Bari bi Syarh al-Bukhari. Riyad, Penerbit Malik Fahd.

Irwanto, Kasim, \& Rahmi (2010). Analisis Situasi Penyandang Disabilitas di Indonesia. Jakarta: Pusat Kajian Disabilitas Fakultas Ilmu Sosial \& Politik.

Izzuddin bin Abd Salam (1996). Qawaid al-Ahkam fi Masalih al-Anam. Beirut: Darul Makrifat. (1986). Kitab al-Fatawa. Beirut: Darul Makrifat.

Masri Simarimbun dalam Cholil Nafis, Fikih Keluarga; Menuju Keluarga Sakinah Mawaddah wa Rahmah; Keluarga Sehat Sejahtera dan Berkualitas (Jakarta Selatan: Mitra Abadi Press, 2014), hal.72.

Abu Zahrah, Muhammad (2000). Ushûl Al-Fiqh, Saefullah Ma'shum (pent.). Jakarta: Pustaka Firdaus.

Al-Yubi, Muhammad Sa'ad (1998). Maqashid as-Syariah al-Islamiyah wa Alaqatuha bi al-Adillah as-Syar'iyah. Riyad: Dar al-Hijrah.

Az-Zuhaili, Wahbah (1406 H). Ushul al-Fiqh al-Islami. Sirya: Darul Fikr. 
(2000) Taghayyur Al-Ijtihad. Damaskus: Darl al-Maktabi.

Al-Anshari, Zakariya (tt). Ghayah al-Wushul fi Syarh Lubb al-Ushul. Mesir: Dar Kotob Arabiyah Kubra.

\section{Jurnal:}

Mutakin, Ali (2017). "Teori Maqashid Syariah dan Hubungannya dengan Metode Istinbath Hukum”. Kanun Jurnal Hukum Islam, 19.

Mth, Asmuni (2005). "Studi Pemikiran Al-Maqashid; Upaya Menemukan Fondasi Ijtihad Akademik yang Dinamis" Al-Mawarid Journal of Islamic Law, 14.

Shidiq, Ghafar (2009). “Teori Maqâshid Al-Syarî’ah Dalam Hukum Islam” Jurnal Sultan Agung, 118.

\section{Berita:}

Redaksi, (10 Maret 2020). "Jumlah Penduduk Indonesia 2019 Mencapai 267 Juta Jiwa". www.databoks.katadata.co.id.

Adrian, Kevin (11 Maret 2020). "Cara Menjaga Kesehatan Reproduksi Wanita". www.alodokter.com.

Kuamila, Ajeng (11 Maret 2020). "Cara Menghitung Indeks Massa Tubuh (Body Mass Index)". www.hellosehat.com.

Kirana, (11 Maret 2020). "Di Rakesnas 2019, Dirjen Kesmas Paparkan Strategi Penurunan AKI dan Neonatal". www.kesmas.kemkes.go.id.

Muhammad, Hamid (11 Maret 2020). "Sekolah Inklusi dan Pembangunan SLB Dukung Pendidikan Inklusi”. www.kemdikbud.go.id.

Redaksi, (10 Maret 2020). "2015-2045: Angka Kematian Terus Naik, Angka Kelahiran Relatif Stabil”. www.databoks.katadata.co.id. 